\title{
Obituary
}

\section{Wallace Spencer Pitcher 1919-2004}

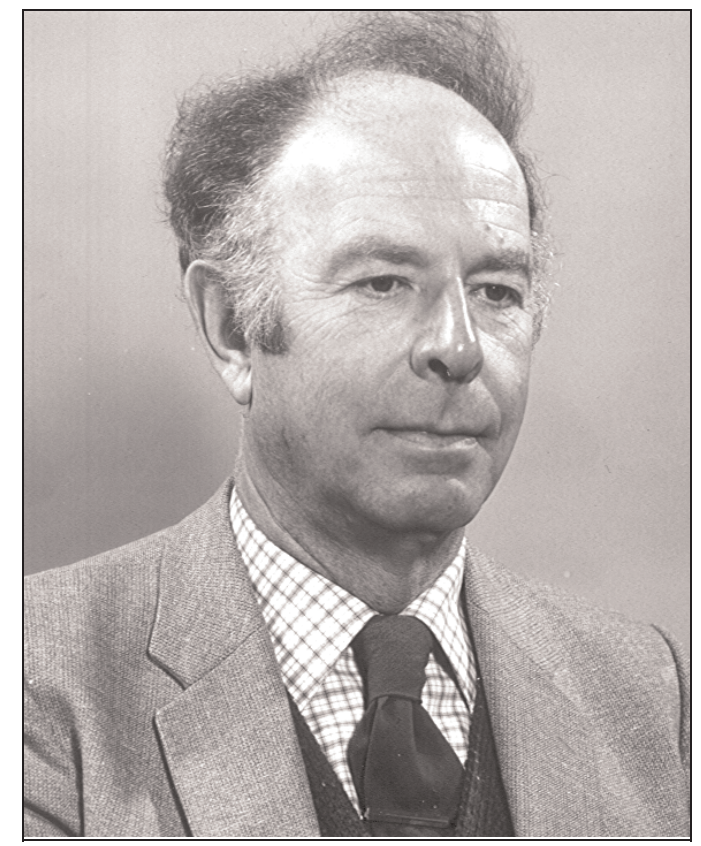

Wally Pitcher, who died on 4 September 2004, was born on 3 March 1919 in Acton, west London and was to become the leading and most distinguished British expert on granites and their emplacement, the geology of Donegal, and, with John Cobbing, the geology of the Peruvian batholith. He joined the Mineralogical Society in 1949 and remained a life-long member.

After local schooling he became, at age 17, an apprentice assayer which introduced him to the art and science of chemical analysis, while his amateur interest in the local London Clay developed into expertise in the Tertiary fauna in the formation. He combined these aspects in studying for a part-time BSc in chemistry and geology at Chelsea College but the Second World War intervened before he graduated, and he entered the Army. His occupation as a 'chemist' resulted in him being considered a 'pharmacist' and he became a sergeant medical orderly in the RAMC from 1939 to 1944 , when he was released to re-enter Chelsea College, full-time and graduate in 1947, aged 28. He joined the Geologists' Association as early as 1942, leading excursions after the war and eventually (1973) becoming an Honorary Member.

His first post was at Imperial College, initially as Demonstrator in Geology (1947-8), then as Assistant Lecturer (1948-50) and finally as Lecturer (1950-55), under the towering Professor H.H. Read, the leading proponent of granite being formed by transforming metamorphic rocks rather than being produced from primary magma. Read was attracted to studying the Donegal granites because it was clear that metasediments were intimately involved with, and were enclosed by, some of the granites, suggesting to Read that their study would provide a convincing proof of granitization. $\mathrm{He}$ put Pitcher onto studying the problem which required mapping the Donegal granites and the country rocks. This started a major 25 year 
programme of research in which dozens of researchers would become involved. Pitcher's own PhD (1951) was on the Thorr Granite. Pitcher was responsible for starting the first rapid silicate rock analyses in Britain as part of this project, during 1952-3, which was how and when the writer first met Wally. He was a calm, unruffled, hard-working, rather ponderousspeaking, gentlemanly-type who was an excellent teacher, and whose under-rated diplomatic skills were even able to convince the dogmatic Read that, far from proving a granitization origin for the Donegal granites, the great project had only confirmed a magmatic origin with the enclosed country rocks being xenoliths! The detail of the mapping, plus the generally good exposure, opened the way to a concurrent major revision of the structure and stratigraphy of the Dalradian country rocks, including the re-discovery of the key correlating horizon of the Portaskaig Boulder Bed. Mineralogically he ensured the Donegal beryl locality remained unpublicized. The Donegal results appeared in summary form in 1972 in the great book on The Geology of Donegal; a Study of Granite Emplacement and Unroofing, co-authored with A. Berger.

In 1955, Pitcher moved to King's College London as Reader in Geology and then in 1962 to the George Herdman Chair of Geology in the University of Liverpool, where he remained until formal retirement in 1981. In Liverpool he initiated a major study of the Peruvian batholith, involving arduous field work, again with a number of other researchers, in particular Dr Cobbing. The study of the supra-subduction zone granite related to the Pacific margin, culminated in 1985 in the book, Magmatism at a Plate Edge: the Peruvian Andes. After 1981, he continued to research as vigorously as before and distilled his enormous knowledge of granites and the literature on granites into a major book The
Nature and Origin of Granite (1993), which went into a second edition in 1997, and was followed by his last publication, A Master Class Guide to the Granites of Donegal, (2003) (reviewed on p. 222, this issue).

Pitcher served the profession in too many ways to list in full here, but was significantly responsible for pulling the Geological Society out of the 1960s mess and for gently persuading the numerous Specialist Groups to retain allegiance to the Society by being flexible in the forms of alliance. He was a great conciliator. $\mathrm{He}$ was Secretary (1970-3), Foreign Secretary (1974-5) and President (1977-8) of the Geological Society, received the Lyell Fund (1956), the Bigsby Medal (1963) and the Murchison Medal (1979). His two Presidential addresses, The anatomy of a batholith (1977) and The nature, ascent and emplacement of granitic magmas (1978) are among the diminishing number of great Presidential addresses. He was a founder member and medallist of the Institution of Geologists and was the recipient of many honours, being Honorary MRIA (1977), FRSE (1993), F. Geol. Soc. Amer. (1982) and, apart from an earned DSc (Lond., 1964), held Honorary DScs from Dublin (1983) and Paris-Sud (1993), and medals from the Liverpool and Helsinki Geological Societies. He was unassuming, greatly loved and respected by his very many students, a little ponderous but not pompous.

His wife of 57 years, Stella, née Scutt, whom he married in 1947 and with whom he had two sons and two daughters, was an enormous help and support to him and was indirectly responsible for much of his success.

[A much fuller account will appear in the Royal Society of Edinburgh's website: www.royalsoced. org.uk]

B. E. LEAKE 